\title{
造粒物強度の試験法と評価
}

\section{Test Methods for Evaluating the Strength of Granules and Agglomerates}

関 口 動*
Isao SEKIGUCHI

\author{
Key Words : Granule, Agglomerate, Strength Test Method, \\ Tumbler Strength, Crushing Strength, Shatter Strength
}

\section{1. はじめに}

造粒物の機械的強度試験は造粒操作を取り扱う多様 な産業分野で実施されており，この強度試験法は原料 から造粒製品，そしてその用途目的に至るまでの工程 や品質の管理にとって重要な材料試験法の意義をもっ ている。特に, 造粒操作では, その目的に対応させた 原料調製を経て最適な形状, 大きさ, 構造, 組成など の造粒物をつくるため, このような造粒物の材料力学 的な性質を一義的に決めることは難しい点が多い11,2)。 すなわち, 原料の種類あるいは物性が異なれば, 同一 の造粒装置・操作における造粒品の強度は当然のこと ながら変わる。また, 同一の原料でも装置の種類と操 作条件が異なれば, 製造された造粒品の強度は変動す るのが通例である。基本的に造粒プロセスは, 造粒目 的一原料調製一造粒プロセス一造粒品の評価という一 連の過程からなり, 最後の造粒品の評価の部分は形態 制御としての造粒効果を判断するうえで圧壊, 衝撃お よび摩耗の各強度, これらに付随して見掛け密度, か さ密度, 流動度などのハンドリングに関連した特性の 測定評価が実施される。もちろん,この他には業種特 有の造粒品の使用目的に対応した具体的な評価の方法 もあるが, 上述のような造粒品の評価がまず先決的な 事項となる。

すでに(社)日本粉体工業技術協会編「粉体工業関連 規格集(第1集)」3)には，造粒物関連として 5 件の協会 規格が揭載されており,このうちの造粒物強度につい

1994年 8 月 4 日受付

* 中央大学理工学部応用化学科 ( 7112 文京区春日 1-13-27)

TEL. 03-3817-1913
ては日本工業規格 $(\text { JIS })^{4)}$ に制定されている。そこで, 本稿では造粒物関連の強度試験と評価の方法, ならび にその周辺の紹介と解説を試みることにした。

\section{2. 意義と分類}

外見上, 造粒物強度の測定そのものは簡単のようで あるが，その目的や評価については多様な問題が介在 している。図 1 は造粒物の各種機械的強度を中心とし て関連する事項の相関関係を表わす。基本的には造粒 目的 $\rightarrow$ 原料処理 $\rightarrow$ 造粒装置・操作 $\rightarrow$ 後処理 $\rightarrow$ 目的のサ イクルがあって,それぞれには常に造粒物の形態保持 (適切な保形)に必要な強度問題が密接な結び付きをも っている。ここでは少なくとも次の三つの事項が深く かかわる。

(1) 多数の造粒物を対象にしたサンプリングの方法 と試験数, ならびに測定值の統計的評価法について。

（2）強度試験機の構造と選択，これに付随する精度 と測定方法について。

(3) 造粒物の強度試験結果の評価に関する効果的な

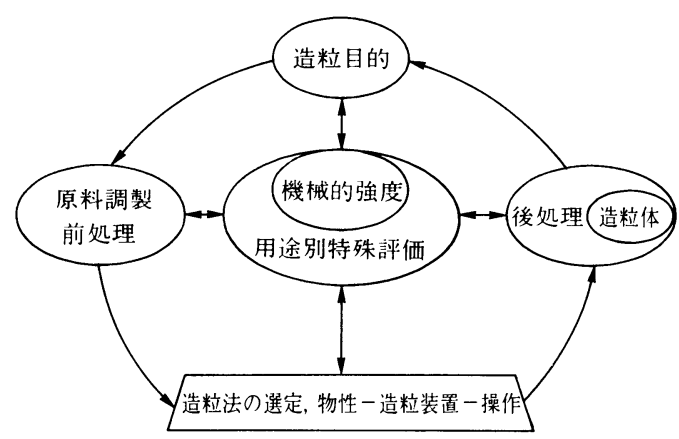

図 1 造粒物の機械的強度とその周辺の相互関係 
適用方法について。

しかし, 承知のように造粒物は, 食品, 飼料, 肥料, 医薬, 農薬, 触媒, 七ラミックス, 鉱業, その他の工 業薬品などの業種特有の中間製品ないしは最終製品と して製造され，それらの大きさ，形状，構造，組成， 強度などは業種に対応して使用の目的や条件に最適で あることが要求される。こうなると，(1)〜 (3)の事項 についてはそれぞれの業種，あるいは造粒物の種類 (特に，材質）によって多様な対応の仕方がでてくる。

\section{1 試験前の留意点}

特に，上記の(1) と(3)の内容は異質の業種において も普遍的な意義を認めうるが，かなり異なった手法が 用いられる。（1）に関連して，サンプリングについて はQC (品質管理)の進歩によって多くの分野で採用さ れている問題であるが，例えば粉・粒・塊状物質に関 するサンプリングはすでにJIS M 81005)によりコサ インメントからの特性の平均值を決定する一般的事項 が規定されている。造粒物についてはこの種の規格が 中心的な役割を果たすか，あるいは準用されうる。通 常，コサイメントを構成するロット(またはサブロッ ト)のサンプリングが対象とされるから，このロット の中身は一様であるという前提条件がある。ゆえに， これから得られる試料は統計学的に信頼性が高く, そ のための無作為な採取で，かつ試料の数が多くなる。 この試料の数は後記の圧壊強度試験において造粒物 1 個を対象にすると(通常，単位体という)，その試料の 単位が個数となる。ただし，層状(または堆積)造粒物 に対する荷重時の圧壊問題では試料単位を質量とする であろう。同様に, ほかの摩耗強度ないしは衝撃強度 の場合には多数個(通常，集合体とみなす)，すなわち その単位量として質量を用いることが一般であるが, たとえば錠剤のように造粒物 1 個を对象(単位体)にす るときには試料の単位を個数とする場合がある。要す るに，単位体または集合体とするかは造粒物の種類や 試験目的によって根本的に異なるが，サンプリングの 統計的意義については何ら変わることがなく，インク リメント(サンプリングにおいて採取した単位量)の大 きさの選び方はその動作間のバラッキを少ないように 工夫する必要がある。個々のサンプリングの種類や精 度の詳細については省略するが, 特に平均の区間推定 におけるサンプリングの精度計算には信頼度 $95 \%$ と するのが標準的であって, これによってインクリメン トが決まってくる。もちろん，この精度は造粒物の強 度試験法あるいは品種によって異なる場合があるか ら，サンプリング方法は業種特有のものとして確立し
ておく必要がある。さらにサンプリングとしては造粒 物の製造時から輸送, 供給, 包装など, それに商品と しての受渡しに至るまでが対象となる。

\section{2 強度試験法の分類}

造粒物の種類とその取扱い方は業種によって多様で あるから，造粒物の強度試験は業種ないしは業界特有 の方法で実施されている。それらを総括すると，典型 的な強度試験法は図 2 のような例が挙げられる。図中 の各強度試験法は, (1)から8)までの静的強度試験法 (圧縮 /(引張), 引張), ならびに(9)から(20)までの動的 強度試験法(衝撃, 摩耗, 衝撃/摩耗)のように大きく 分類される。この他には, 例えば輸送, 貯蔵, 供給, 計量, 包装などにおいて造粒物強度の耐久性を調べる 観点から，これらの諸機能を備えた小規模実験装置を つくり, 実際面に近い造粒物の強度試験を実施する場 合もある。

静的強度における最も代表的な試験法は，2平面間 の球状造粒物を対象とする(1)(a)の圧壊試験法(圧壊 強度表示)であり，これにより引張強度を間接的に調 ベることがある。(2)(a)の点荷重法は不規則形状の造 粒物に用いられる場合もあるが，この方法はむしろ岩 石 (鉱石) 類の強度試験 ${ }^{6}$ に用いられる。造粒物の集合体 に対しては，(3)のように壁面摩擦抵抗を省略しうる程 度の浅い層を圧縮して造粒物の崩壊状況を調べたり7), あるいは(4)のように積載時の袋詰造粒物群の崩壊(ま たは付着)を予測するための試験法が挙げられる。引 張試験法では，(5)のうに造粒物を削って治具に接着 したり，あるいは分割セル内に挿入する6の方法があ るが,これらは余り用いられない。治具に接着しない 簡便さから，(7)または(8)の圧裂引張強度試験法 ${ }^{8.9)}$ (別 名ではBrazilian testともいう)が多用されているが, 理論的に純粋な引張状態ではないことに留意する必要 がある。

動的強度については衝撃, 摩耗およびその両機構 (衝撃/摩耗)のように分けられる。衝撃試験法で最も 使用頻度の高い落下強度試験方法は9の例であり, す でに鉄鉱石焼結鉱 ${ }^{10)}$ ，コークス類 ${ }^{11)}$ などで採用されて いる。衝撃波形分析による例では，(100振子式ハンマ 一による錠剂衝撃強度測定 ${ }^{12)}$ ，あるいは(12)の落下重鏵 もあるが，これらは通常の強度試験法というよりも試 験研究用の特殊型に属する。(11)のリフタ一付回転ドラ 么では造粒物試料を多く用いると摩耗と衝撃の区別が 不明瞭になる。摩耗強度の観点では, (13)の回転ドラム 型，あるいはそのドラム内の造粒物試料のカスケード 流れに近い挙動のもとで造粒物の摩耗を調べる(14)の管 
(A)

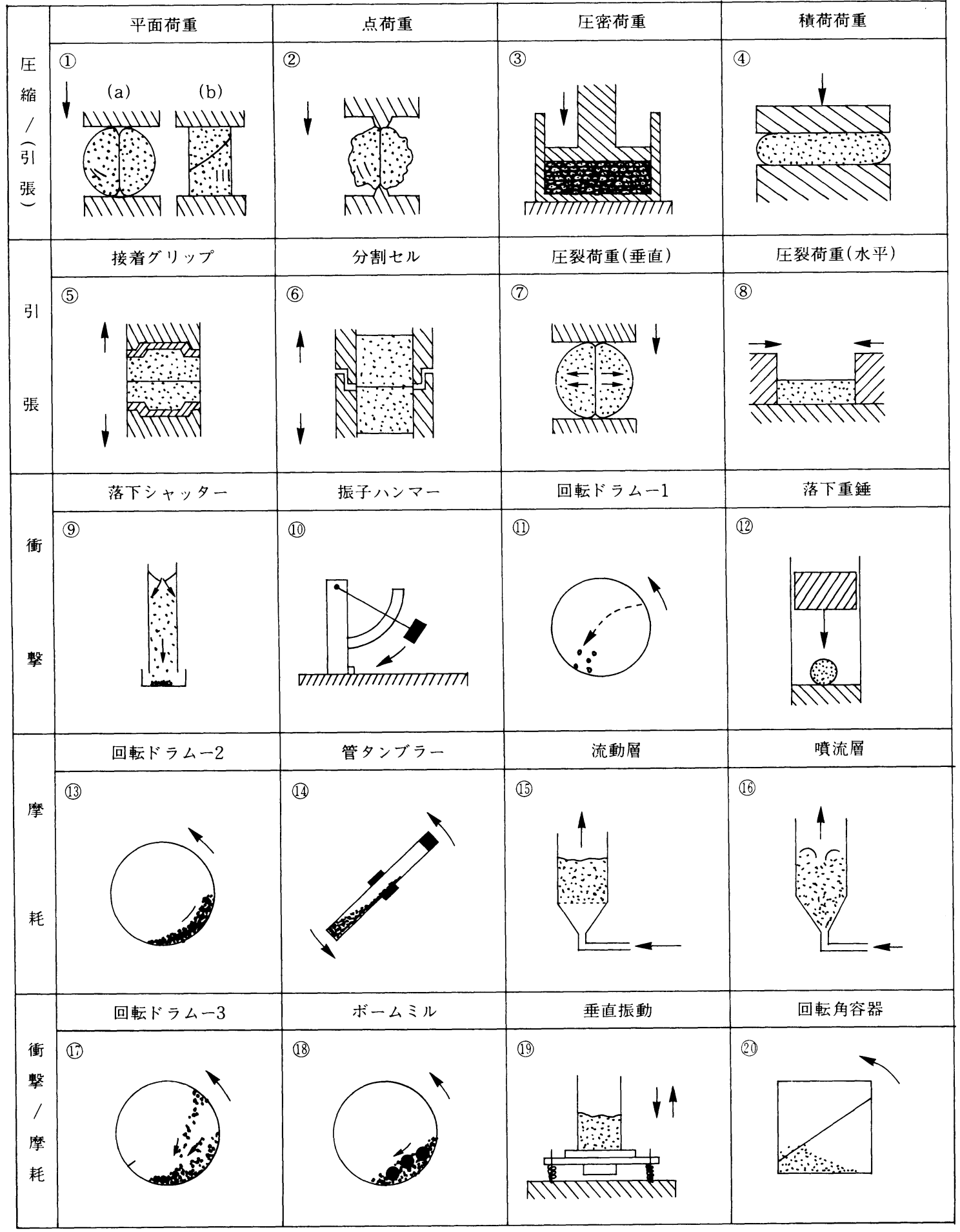

図 2 造粒物の各種強度試験法の分類 
(B)

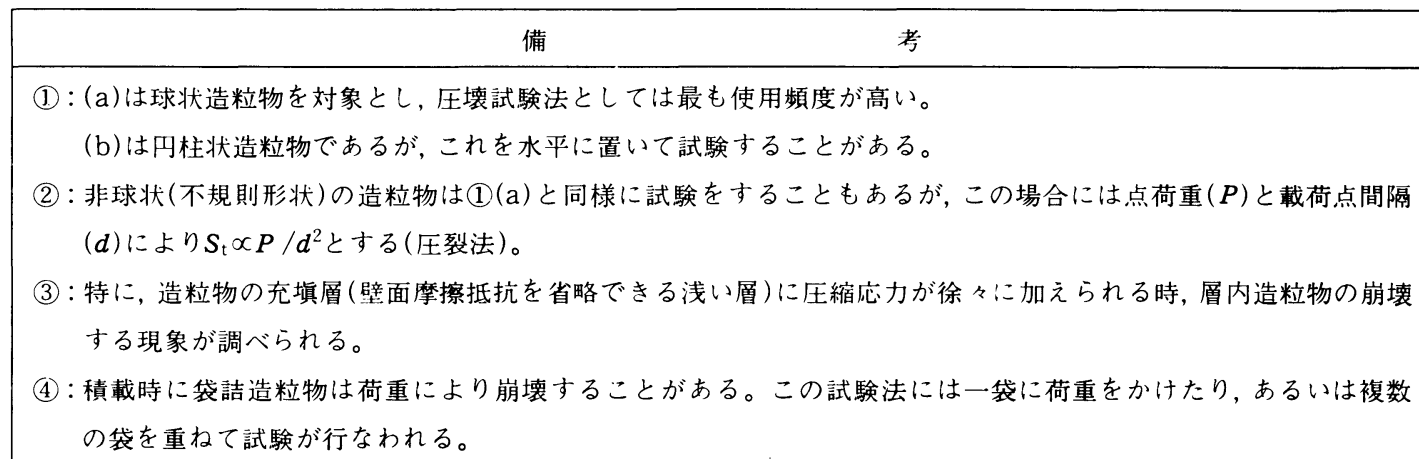

(5)：造粒物は引張試験用固定治具に接着しやすいようにカット加エし，この造粒物は 2 個の固定治具間に接着して引 張試験が行なわれる。接着郕は造粒物内に深く侵入しないものを選ぶ。

(6)：この方法はほとんど造粒物の引張強度試験に用いられないが, 七ル内壁には円柱状にカットした造粒物(成形 物)を接着固定の必要がある。

(7): 円板形の造粒物(典型例: 錠剤)を対象として直径方向から載荷する。この試験法は圧裂引張試験法(別名 :Brazilian test)という。

(8): (7)と同様であるが, 円板形造粒物は直径方向を水平にして置く。

(9):一定重量の造粒物群を, 底板が観音開きになるように作られた容器に入れ，所定の高さから鋼板上に落下させた 後, ふるい分析を行なう。

(10):アンビル・造粒物に对して振子式ハンマーで衝撃を与え，この時の衝撃波形の分析が必要である。基本的には 破壊時の最大衝撃力を用いる。

(11)：ここでは衝撃用に分類してあるが, ドラム内壁に固定してある搔上板(リフター, フライト, 羽根) 1 枚から造粒 物が放出され，この飛行造粒物がドラム内壁面へ衝突することを原理とする。

(12)：重錘をアンビル上の造粒物に落下衝突ざせこの時の衝撃波形の情報から(10)同様の方法で衝擊強度に関する データが得られる。

(13):一定重量の造粒物をドラムに入れ，かつ所定の回転速度のもとでドラムを回転させ, 所定の試験時間の後, 試料は ドラムから完全に排出し，ふるい分析により粉化率を決める。回転速度/臨界回転速度は $0.40 \sim 0.55$ 程度である。

(14)：例えば,一定の造粒物をガラス管(複数もある)に入れ, 管の両端口をゴム栓(材質で衝撃状況が異なる)でふさ

ぐ。試験方法は13と同様である。

(15) : 所定のガス流速のもとで,一定重量の造粒物(触媒の場合が多い)を流動化させ, 時間の経過とともに造粒物の粉 化率の変化が調べられる。

(16):この場合は115)と同様であるが, 噴流層特有の循環流を伴うときの造粒物の粉化率が得られる。

(11)：一定重量の造粒物をドラムに入れ，この搔上板付回転ドラムによって粉化率が測定される。試験法は1(13)とほぼ 同様であるが, 搔上板から放出される造粒物の衝撃現象が介在しやすい。

(18)：試験法は(13)，(11)と同様であるが, 3個以上のボールによる破砕や摩耗の現象が介在する。

(19): 一定重量の造粒物は特定の振動のもとで相互の衝撃や摩耗が発生し, 粉化率と時間の関係が得られ, これには容 器の形状や材質の影響もありうる。

(20) : 搔上板付回転ドラムと同様であるが, ドラムの代わりに角形容器が用いられ, 容器内壁には通常, 1 枚の搔上板が 付設される。 
タンブラ一型131がある。通気による造粒物の摩耗強度 試験には, 主として触媒粒の摩耗試験(Attrition testともいう)に用いられていた(15)の例 ${ }^{14)}$ ，または噴 流と循環流を伴う(16の噴流層型も見受けられる ${ }^{15)}$ 。衝 撃と摩耗の両機構が混在するか, またはその判別が不 明である例としては117のリフタ一付回転ドラムや18の ボールミルの方法がある。前者は(13)の場合と似ている が, このリフタ一付では造粒物の降下衝突による崩壊 現象に注意を要する。この点は造粒物の材質に依存す ると推定される。この種のリフターによる造粒物の降 下が摩耗試験に影響しなければ, (17)の試験法はほぼ転 動作用による造粒物の摩耗試験に属する。(13)試験法 では造粒物がドラム内壁面に沿って不規則な滑り現象 を生じやすいので，一般には117)回転ドラムによる摩 耗試験を実施する場合が多い。全農法と称しているボ 一ルミル (18) ${ }^{16)}$ は顆粒状の農薬に用いられたり, あるい は回転角容器(別名：耐久性指数測定器)(216)はペレッ 卜状飼料を対象にした特殊用途の試験法である。(19)の 垂直振動の方法は, 一般に容器内造粒物の振動による 衝撃と摩耗の試験用であって, 特に輸送時における造 粒物の崩壊状態を調べるのに便利である。

\section{3. 典型的な造粒物強度試験法と評価法}

造粒物の静的または動的な強度試験法は, 前述のよ うに多様な目的に沿って, それぞれに特徴的な試験法 が挙げられる。これらの一部はすでにJIS，団体また は社内の規格になっていたり，あるいは慣習的に実施 されている場合もある。したがって，同一の種類に属 する強度試験であっても試験装置の構造, 寸法, 材質, 操作などの点, あるいは試験結果の評価とその表示法 については異なることがある。静的強度試験の場合に は多くの試験例において著しい相違点はないのである が, 動的強度試験では衝撃と摩耗の境界が不明確であ ったり，あるいは意図してその両者を含めたような試 験法がある。さらにこの種の試験法での評価には, 多 少の破壊を伴う造粒物があったとしても，主として摩 耗による粉末化を厳しく判断したり, あるいはその逆 の現象である粉末生成よりも衝撃破壊( 1 個の造粒物 が数個の破片に分裂または亀裂)を重視することがあ る。これらの判断基準は造粒物の種類ないしは業種特 有のものであるから,このような立場では普遍的な造 粒物強度試験法の確立は難しくなる。そこで, 以下に は造粒物強度の評価基準を別の問題として, 造粒物に かかわる一般的な強度試験法の概要を紹介する。

\section{1 静的強度試験法}

この試験法は，一般に 2 評面間の造粒物 1 個に対し て静的に力を加えてゆき，その造粒物に亀裂を生じさ せたときの力が強度值の表示となる。この強度值の名 称には硬度, 圧縮強度, 圧潰強度, 圧壊強度などが挙 げられるが，ここではJIS ${ }^{4)}$ と対応させて圧壊強度の 名称を用いる。この圧壊強度は単純な現象のようであ るが, 強度值に内材する特性要因は図 3で示すように 複雑である。図の上の部分は試験法にかかわる試験機 の精度や試験条件である。その下部に示してある造粒 物は粉体凝集体の顆粒やペレットのような例である が, それらの材質は原料調製一造粒装置・操作一後処 理の方式によって構造, 形状, 組成などの点で多様な 影響を受けており, この他のプリル, ビーズなどの単 一体状の造粒物も同様である。要するに, この種の試 験法は造粒物の強度的な品質を管理するのではなく, むしろその試験によって使用条件に適合した造粒物の 生産工程を管理することが主要な目的と考えられよう。

圧壊強度試験機における荷重の伝達方式には, ばね 式, てこ式, 電動式, 油圧回路式などがあって, それ ぞれに特徴があるものの精度の観点では荷重の指示機 構を含めて検討しておくことが重要である。この精度 にはサンプリング, 機器, 測定者, 雾囲気などの誤差 を含むが，ここでの精度とは測定機器に限定してみ る。図 4 は, (a)ばね式硬度計と (b) 油圧回路式圧壊強 度試験機(ロードセル型検出器, 増幅器, 記録計を含 む)を用いて焼成ゼオライト凝集造粒物(球状)の圧壊 強度を測定した例を示す。ばね式の方は簡便に測定で きる点で有利であるが, 圧壊強度值 $\left(4 P /\left(\pi x^{2}\right), P\right.$ : 破壊荷重, $x$ : 造粒物直径)のバラツキは(b)の場合に 比べて(a)の方が大きい。これはばね機構による造粒 物の破壞点の指示が難しいためと推定される。やはり

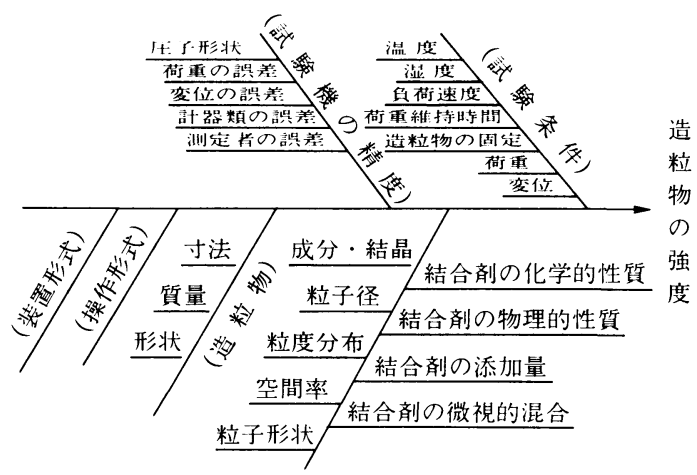

（造粒物の材質）

図 3 造粒物の圧壊強度に関する特性要因 

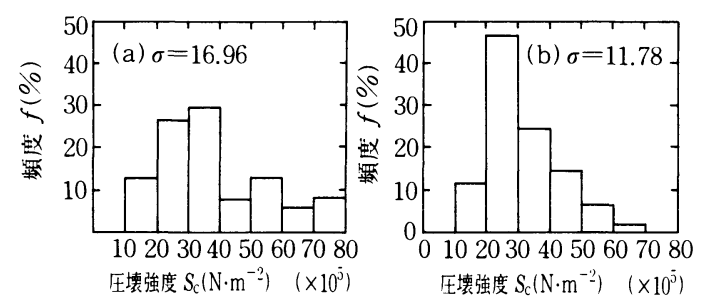

図 4 (a)ばね式と (b) 油圧回路式の両試験機を用いて球状 ゼオライト(バインダーで凝集造粒後に焼成)の圧壊 強度を測定した例

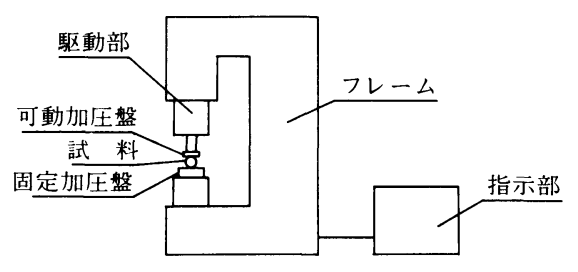

図 5 圧壊強度試験機の構成例(JIS Z 8841-1993)

造粒物の破壞は亀裂を生じるところが基本であるか ら，図 5 で例示するように圧壊強度試験機は，造粒物 試料 1 個を圧壊する機構の荷重部，ならびに荷重の指 示記緑を行なう指示部から構成されることが最も標準 的である。荷重部ではその荷重伝達方式として一定の 加圧盤速度に制御しうるものとし, それに荷重検出器 （例，ロードセル)を備えておく。荷重の方向は垂直ま たは水平でもよいが, 後者では水評試料台の上に造粒 物をのせ, 水平方向から両加圧盤により圧壊させる方 法である。この後者の場合には造粒物の接触変形が大 きくなると, 接触面の搪大に伴う半径方向(接触円)の 摩擦抵抗が生じやすく, 特にこれと同時に造粒物の変 形が大きいようであれば, このような変形の大きい造 粒物では両加圧盤のみならず水平試料台表面からも圧 縮力を受ける点に注意を要する。指示部では荷重と変 位との関係を時間の経過とともに指示記録できる機器 (例 : 増幅器と記録計)があればよい。以上の諸点に留

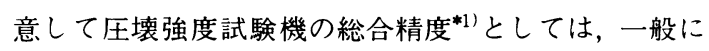

*1) この場合の総合精度 $\sigma \mathrm{T}$ は, 荷重検出器の精度 : $\sigma_{1}= \pm a(\%)$ F.S., 電気計器の精度 : $\sigma_{2}= \pm b(\%)$ F.S., 記録計の精度 : $\sigma_{3}= \pm c(\%)$ F.S. とすれば, $\sigma_{\mathrm{T}}=\left(\sigma_{1}{ }^{2}+\sigma_{2}{ }^{2}+\sigma_{3}{ }^{2}\right)^{1 / 2}$ のよう に表わされる。一般に荷重検出器, 電気計器, 記録計などに は, 仕様に非直線性, 出力, 電源変化, 温度変化, 時間変化 などに对する精度表示があるので，これらから総合的な精 度の検討が必要な場合もある。しかし，通常の機器類およ び環境条件では土1.00\%以内での総合精度をほぼ満足でき る状況である。この他, 定格容量(例: ロード七ル検出器)に 対する測定值の比, 感度(例: 記録計)とフルスケールの関倸 などの設定方法が測定結果の確かさに影響することに留意 されたい。

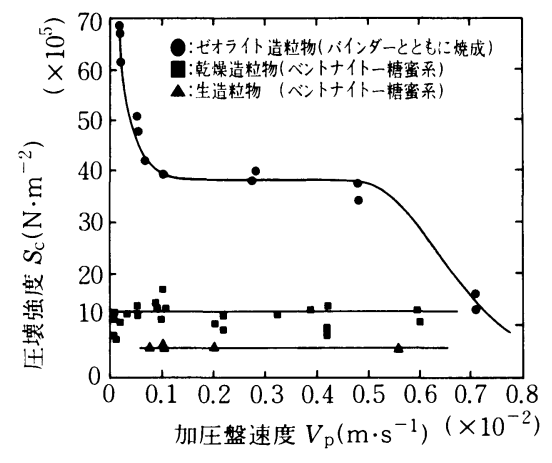

図 6 球状造粒物の圧壊強度における典型的な加圧盤速度 の影響(造粒物：図 4 の試料と同様)

市販されているロードセル検出器, 電気計器(例: 増 幅器) および記録計の各精度から $\pm 1.00 \%$ 以内にする ことが望ましい。なお, 加圧盤速度と圧壊強度との関 係は, 例えば図 6 のように変動しやすい場合がある。加 圧盤速度が遅いときには, 特に両加圧盤との接触面で 球状造粒物の一部破壊によって応力分散を生じ, 強度 が高めに記録されたり，あるいは応力の速い伝播速度 に起因して強度が低めに記録されることがある4)(図 中のデータにはない)。しかし, 加圧盤速度が極端に 速いときには，図で示すように圧壊強度は造粒物への 負荷速度が速いために試験機の応答速度が追随できな くなり，低めの強度を示す場合がある。したがって， 加圧盤速度は強度の一定值を与える範囲内が適当であ ク, 特に造粒物の圧壊特性や試験機の特性を考虑して 決められる。加圧盤速度は一般に0.15 0.30 mm / sの 場合が多いのであるが，実際には造粒物の材質や試験 機の特性に対応した加圧盤速度を予備試験で調べてお くとよい。

圧壊強度の表示は, 多様な形状や材質の造粒物を対 象とするために試験の条件や経過を明示し，まず記録 計から確認された最大荷重(力)が用いられる。造粒物 1 個は加圧盤間において試験されるので, 球状以外の 造粒物は荷重の伝達方向を決めておく必要がある。通 常, 厚い円板状の造粒物(例: 錠剂)では圧裂引張強度 試験法に準拠して造粒物の直径方向に荷重 (圧縮応力) を伝達するようし，円柱状造粒物 (例：飼料ペレット) も同様の形式をとることが多い。造粒物の大きさの次 元は当然, 強度に対して影響を与えるので, 例えば直 径 $x$ の球状造粒物の圧壊強度 $S_{\mathrm{c}}$ では破壊荷重を $P$ とし $\tau S_{\mathrm{c}}=4 P /\left(\pi x^{2}\right)$ とする。この破壊機構は球中心線で の破断面(二つの半球状に破壊)を仮定すると引張強度 を表わすことになる17)。これと対比する意味で岩石類 の球形試験については理論式 $S_{\mathrm{c}}=2.8 P /\left(\pi x^{2}\right)$ の例 ${ }^{6)}$ 


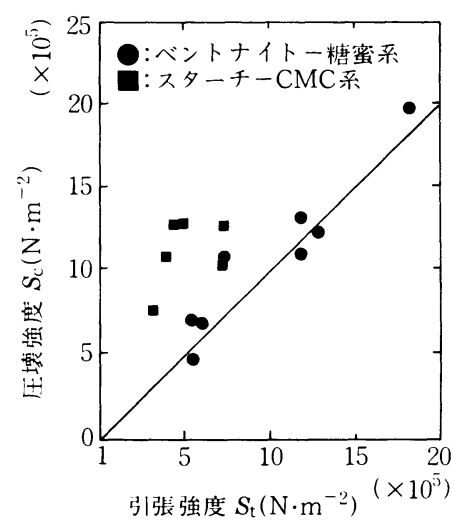

図 7 球状造粒物の圧壊強度 $\left(S_{\mathrm{c}}\right)$ と引張強度 $\left(S_{\mathrm{t}}\right)$ の関係

があり，これは引張強度 $S_{\mathrm{t}}$ でもある。しかし, 多様な 材質からなる造粒物では, ぜい性度からみて $B_{\mathrm{r}}=S_{\mathrm{c}} /$ $S_{\mathrm{t}}=1$ になることは稀であって，例えば図7のように $S_{c} / S_{\mathrm{t}} \geqq 10$ 傾向になりやすい。いずれにしても, 球状 造粒物では一般に材質上の力学的特性(材料力学的定 数), 加圧盤接触時の変形(接触円) などによる破壊機 構が不明であるため, 寸法効果を含めた破壊荷重 $P$ と 直径 $x$ との関係は, $P=k x^{\mathrm{n}}(\mathrm{n}=1 \sim 2.5)$ とし, 通常では $\mathrm{n}=2$ になることが多く, $k$ は強度係数として表わす方 法がある。また, 圧裂引張強度試験法では, 両加圧盤 から圧縮すると, 円板の内部に中心線に沿って左右に 引張応力が生じ, ついに引張破壊が起きる。このとき の応力, すなわち引張強度 $S_{\mathrm{t}}$ は荷重 $P$ で, 厚みlの円板 の直径を $x$ として $S_{\mathrm{t}}=2 P /(\pi l x)$ である。この円板内 の応力状態の解析 ${ }^{8)}$ によれば, この種の試験法では純 粋な引張強度とはならないが, この方法は簡便な引張 強度試験法として用いられる。結局, 多様な形状と材 質の造粒物を対象とした典型的な静的強度試験法にお ける圧壊強度の表示は, 個々の荷重の伝達方式を明ら かにし，そして単に破壊荷重(力)を用いることが普遍 的で，かつ標準的である。しかし，上述のように造粒 物に関して寸法効果, あるいは破壊機構が特定できる ようであれば, 破壊面積(クラック)当たりの力として 表わすことは何ら差し支えない。なお, 完全塑性体 (例：理想粘土球)に近い造粒物は圧壊強度の対象では なく, 新しく塑性変形度のような定義が必要になる。

\section{2 動的強度試験法}

この試験法は, 造粒物が衝撃，摩耗，あるいはその 両作用を受けるときの耐久性(Durability) を調べるの が大きな目的であり，しかも実際面の条件(工程，輸 送, 供給, 用途など)のもとで強度試験を実施するこ とが最も理想的である。しかし, 造粒物の品質管理に
かかわる普段の動的強度試験法としては，小容量のサ ンプルを用いて実際の造粒物のハンドリングに近い試 験機による動的強度の評価が適切である。この観点で は，例えば小規模ハンドリング・システムとしてスクリ ユーコンベア，バケットエレベータ一，およびビンへの スライドと落下の諸機能を備えたYoung式ペレット強 度評価システム(飼料の粉化) $)^{18)}$ が挙げられる(サンプ ル量：約 $4.5 \mathrm{~kg}$, 試験時間 : 10min)。あるいはスタ一 ダスト’80, 都市ごみ(無機物)における人工軽量骨材 製造の例 ${ }^{191}$ では，造粒・乾燥・焼成工程の輸送に必要 な乾燥造粒物の強度を図 8 で示す二つの方法, (a)塩 ビ管による転がり落下法，(b) コンクリート面への直 接落下法)で実験し，これによる非破壞率(造粒物試料 個数:20）と圧壊強度との関係は図 9 で示す。この種 の試験結果で約 $2 \times 10^{5} \mathrm{~N} \cdot \mathrm{m}^{-2}$ 以上の圧壊強度になれば 輸送に耐えるとしている点はそれなりに有益な試験と いえるが，プラントでの厳しい条件を想定した場合に は当事者による実際の経験的な判断に依存する。この 他の流動層分散板上のガスジエットによるFCC 触媒 の摩耗試験 ${ }^{15)}$, 焼成目的による移動層内の骨材造粒物 の破壊試験 ${ }^{31)}$ などのように，造粒物の動的強度試験は 実際面に対応した多様な方法で実施される。これらは 特殊試験法とすれば，より広く一般化した造粒物の動的 強度試験としてはやはり標準化であって，すでに圧壊 強度試験法と一体で制度化 $\left(\mathrm{JIS}^{4)}\right)$ されている。この規 格に当たっては，先行の鉄鋼関連のJIS規格 ${ }^{10,11,20 ~ 22) ~ か ゙ ~}$

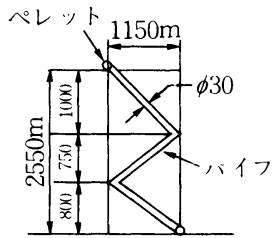

(a)

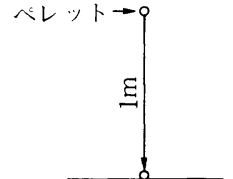

(b)
図 8 人工軽量骨材(乾燥造粒物)の (a) 転がり落下試験法と (b) 直接落下法 ${ }^{19)}$

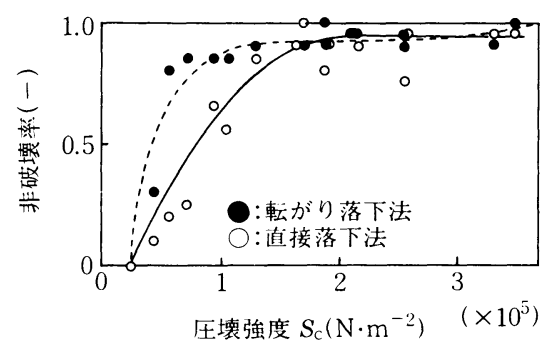

図 9 図8の両試験における非破壊率に及ぼす圧壊強度の影 響 19$)$ 
参考になっているが，試験機類は規格として適正な条 件をつけ，これによる試験結果には多様な造粒物に対 応しやすい表示方式を決めている。

衝撃強度試験のうち, ショア, シャルピーなどの試 験機に類するものは, 衝撃波形の分析により最大衝撃 力 $\left(F_{\mathrm{m}}\right)$ の特定が必要である。あるいは空気圧差 $($ 噴 流)で粒子を加速(衝突速度測定)させてからアンビル へ衝突させる場合には，ヘルツの接触理論から最大衝 撃力を求めるにしても䭪)，造粒物の材料力学定数(ポ アンン比，ヤング率)が不明では計算不可能である。 そこで，多数個の造粒物を一定の高さから繰り返し落 下させ，ふるい分析を行なう落下強度試験法(通常， 落下高さ $: 2 \mathrm{~m}$ 前後)については, 典型的な衝撃強度の 試験法として広く採用されている。JIS ${ }^{4)}$ による落下 強度試験機では，図10で示すような基本構造になって いる。特に, 試料容器の底板は例えばシャッタ一形式 で瞬間的に造粒物を落下させるようにし，鋼製の落下 受容器は厚さ $12 \mathrm{~mm}$ の底板になっている。いわゆるア ンビルに該当する受容器の底板は造粒物の衝撃時にお ける応力波の反射に留意するところであるが，この材 質と厚さは経験的に決めている。試験による落下強度 $S$ は, まず試料容器 $\left(\right.$ 約 $\left.400 \mathrm{~cm}^{3}\right)$ 中の造粒物質量 $m_{0}$ を 5 回繰り返し落下させた後，目的に沿った粒度のふるい 上残留試料質量 $m$ から $s=\left(m / m_{0}\right) \times 100$ で表示す る。一般に，ある粒径 $x$ に着目し，N回落下にあける フルイ上累積質量分率 $R_{\mathrm{N}}(x)$ と $R_{0}(x)(N=0)$ の比は, 図11で示すように落下回数の増加とともに減少する。 図中の $P_{\mathrm{r}}$ は粒径 $x$ における破壊率を表わし*2)，このデ 一夕では力積の関係から大きい造粒物ほど破壊される。 これは落下回数による球状造粒物の破壊確率過程を示 す。また, 9mesh以下に破壊される造粒物の落下強度 Sとしては図12のように形状によって著しい違いを示 すことがある。JIS ${ }^{4}$ では標準的に落下回数を 5 回に 定めているが，この落下強度試験法は多面的に応用す ると興味深い結果が得られる。

摩耗強度試験において最も典型的な回転ドラムを用 いる方法については，まずドラム直径，ドラム内壁面

*2）ある試料について $N$ 回の落下における粒径 $x$ の造粒物の破壊 率 $P_{\mathrm{N}}$ は次式のように定義する。

$P_{\mathrm{N}}=\left[D_{\mathrm{N}}(x)-D_{\mathrm{n}-1}(x)\right] / R_{\mathrm{n}-1}(x)$

ただし, $D(x)$ とR(x)はふるい下とふるい上の累積質量分率 である。また，落下ごとのPNが等しいとき，落下前と $N$ 回 落下後のふるい上累積質量分率である $R_{0}(x)$ と $R_{\mathrm{N}}(x)$ の比は 次式のように表わされる。

$R_{\mathrm{N}}(x) / R_{0}(x)=\left(1-P_{\mathrm{r}}\right)^{\mathrm{N}}$

以上の詳細とデータについては別報》を参照されたい。

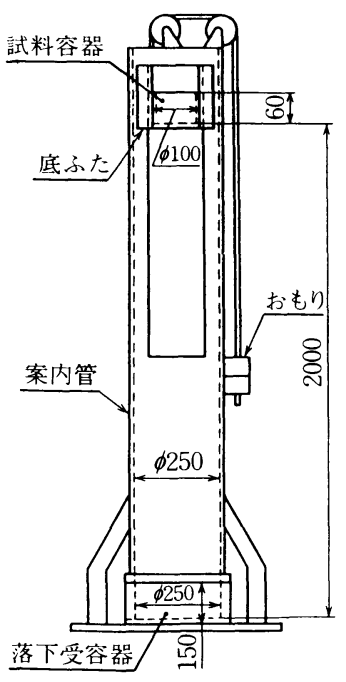

図 10 落下強度試験機の構成例(JIS Z 8841-1993)

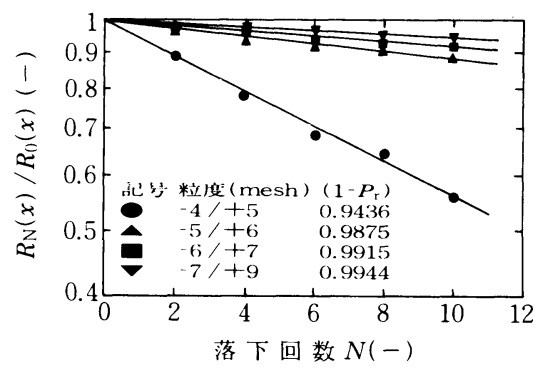

図 11 落下前と N回落下後のフルイ上累積質量分率の比に 対する落下回数と造粒物粒度の影響(試料:ベントナ イト一糖蜜系の乾燥球状造粒物)

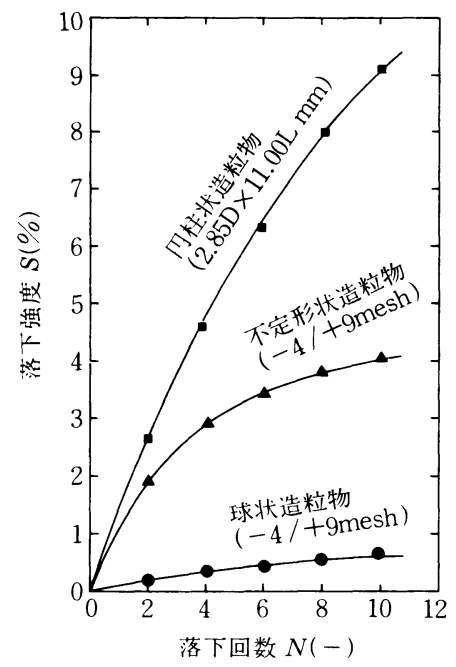

図12 形状の異なるベントナイトー糖蜜系造粒物(乾燥)の 落下強度における落下回数の影響 


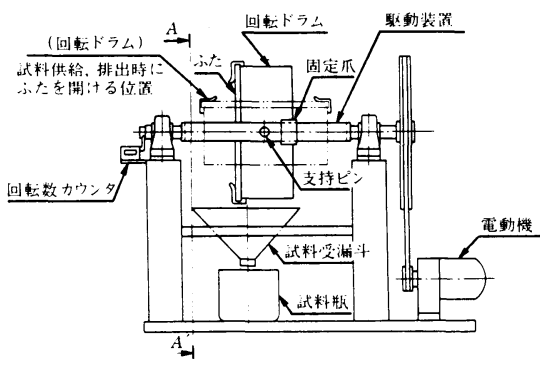

図 13 回転強度試験機の構成例(JIS Z 8841-1993)

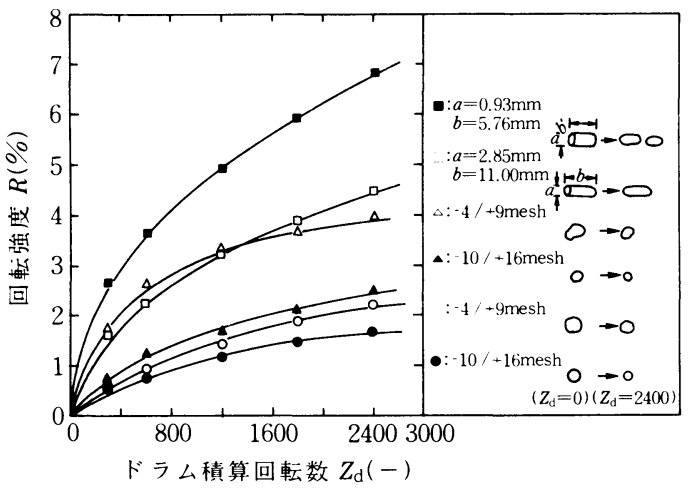

図 14 各種形状のベントナイトー糖蜜系造粒物の回転強度 とドラム積算回転数の関係

の仕上げ，造粒物の滑り防止，試料の出し入れなどの 構造と寸法, ならびに回転速度の設定が重要な事項と なる。JIS ${ }^{4)}$ にる回転ドラム試験機では, 落下強度 試験法と同様に造粒物試料のかさ体積 $400 \mathrm{~cm}^{3}$ を基準 とすると, 図13で示す回転ドラム(内径: $350 \mathrm{~mm}$, 長 さ：175mm)において約 $2.5 \%$ の保有率である。このド ラム内壁面には 2 枚の鋼鈑製リフター(高さ $: 10 \mathrm{~mm}$, 厚さ: $6 \mathrm{~mm})$ が取り付けられている。駆動装置は回転 ドラムの回転速度を $39 \pm 1 \mathrm{rpm}$ に設定できるものとし ている。以上から本試験機による造粒物の摩耗試験で は，基本的に造粒物相互間のこすり作用，ならびにド ラム内壁面と造粒物との間の転動または滑りによるこ すり作用が, 主な破壊力となる状態でドラムを回転さ せることにしてある。積算回転数 200 回における結果 の表示は, 造粒物試料の試験前後の質量を $m_{0}$ と $m$ (所 定の目開きのフルイ上残留質量) として回転強度 $R$ を $R$ $=\left(m / m_{0}\right) \times 100$ とする。ただし, ある造粒物の回転 強度の評価が難しい場合には積算回転数の増減によっ て試験を行ない,その旨を付記しておけばよい。図 14は形状と大きさの異なる造粒物を積算回転数 2400 ま で試験したときの回転強度を示す。特に試験中に破断 するような円柱状の造粒物は, 著しく摩耗して粉化し やすいことがある。基本的に摩耗が継続されれば，す べての造粒物は最終的に消滅して粉末状になる筈であ る*3)。一般に，粉体の凝集による造粒物表面は小さな 凹凸ないしは突起部があり，この凸の部分は試験の初 期に摩耗損失の現象が起きやすい。

\section{4. あとがき}

対象の造粒物は業種特有の品種があるため, その原 料, 製造, 輸送, 供給などから用途に至るまでの品質 の管理は多様である。それらの中にあって造粒物評価 の一つである強度試験法は, 基本的に造粒物の最適な 保形能力を測ることにあるが，そこから得られた情報 はむしろ造粒物の製造プロセスや適正用途に還元され なければならない点に試験法の存在意義がある。ここ では紙数の関係上,そのための造粒物強度にかかわる 材質の要因分析, ないしは機構を取り上げず, 強度試 験法とその特徴のみに集約していることを了解願いた い。なお, 造粒物強度試験法の標準化(圧壊強度, 回 転強度，落下強度）に関する詳細はJIS規格 ${ }^{4)}$ を参照さ れたい。

最後に,このJIS規格制度化の作業には，山下憲一 氏(日本粉体工業技術協会規格検討委員), それに溝口 忠一氏 (大塚鉄工(株))をはじめとして多くの方々の献 身的なご協力があったことに心から謝意を表します。

*3) 球状造粒物の摩耗速度(質量基準)はその造粒物の表面積 ( $\phi_{\mathrm{S}}$ $\left.x^{2}\right)$ に比例するとすれば，摩耗中の造粒物径 $\mathrm{x}$ と時間 $\theta$ の関 係は $x_{0}$ を造粒物初期直径, 比表面積形状係数を $\phi\left(=\phi_{\mathrm{S}} / \phi_{\mathrm{v}}\right)$, $k$ を摩耗係数, $\rho_{\mathrm{b}}$ を造粒物のみかけ密度として

$x=x_{0}-\left(\mathrm{k} \phi / 3 \rho_{\mathrm{b}}\right) \cdot \theta$ のように表わされる。この関係による 粉化率 $X\left(=\mathrm{m} / \mathrm{m}_{0}\right)$ と時間 $\theta$ の関係は次式となる ${ }^{7)}$ 。

$(1-X)^{1 / 3}=1-\left(2 k \phi / \rho_{\mathrm{b}} x_{0}\right) \cdot \theta$

ただし，回転ドラムによる場合は $X$ 回転強度 $R$ (分率)に該 当し, 時間 $\theta$ は積算回転数 $Z_{d}$ とすればよい。

\section{参 考 文 献}

1）関口 勲：粉体と工業，8，49(1976)

2) 中田宏志, 関口 勲, 東畑平一郎: 粉体と工業, 10, 23(1978)

3）日本粉体工業技術協会篇：“粉体工業関連規格集(第 1 集 )”, 広信社・総合工学出板会(1990)
4）JIS Z 8841-1993「造粒物一強度試験方法」

5）JIS M 8100-1984「粉塊混合物のサンプリング方法 通則」

6）平松良雄，岡 行俊，木山英郎：日本鉱業会誌，81, 1024(1965) 
7）関口勲, 中田丢志：粉砕, No. 29号, 28(1985)

8) Timoshenko, S. and J. N. Goodier : Theory of Elasticity, 2nd ed., p. 108, McGraw-Hill(1951)

9) Shinohara, K. : Powder Techn., 32, 163(1982)

10）JIS M 8711-1987「鉄鉱石焼結石の落下強度試験法」

11) ISO 616-1977, Coke-Determination of Shatter indices

12) 誠訪 要: 粉体工学会誌, 18, 199(1981)

13）外山茂樹, 千贺 博：粉体工学研究会誌，4，899(1967)

14) Forsythe, W. L. and W. R. Hertwig : Ind. Eng. Chem., 41, 1200(1949)

15) Werther, J. and W. Xi : Powder Techn., 76, 39 (1993)

16）高山幸英：日本粉体工業技術協会編，“造粒ハンドブ
ック”, p.606「姛料工業における造粒」オーム社 (1991)

17) Kapur, P. C. and D. W. Fuerstenau : J. Am. Ceram. Soc., 50, 14(1967)

18) Young, L. R. and H. B. Pfost : Feedstuffs, 34, 36(1962)

19）内田邦夫, 大竹 武, 富沢 敏, 神谷国男, 伊ケ崎文和, 河村光隆：粉体工学会誌, 19,350(1982)

20）JIS K 2151-1977「コークス類の試験方法」

21）JIS M 8712-1987「鉄鉱石の回転強度試験方法」

22) ISO 3271-1985, Iron ores-Determination of tumbler strength

23) Knight, C. G., M. V. Swain and M. M. Chaudhri : J. Mater, Sci. 12, 1573(1977)

\title{
<書 評
}

\author{
微粒子工学 \\ 一分散の基礎と応用一 \\ 日本粉体工業技術協会 編 \\ （B 5 版 275 ページ 7004円 朝倉書店 1994年発行） \\ 4. 凝集・分散はこう評価する \\ 5. 解砕における分散技術 \\ 6. 分級における分散技術 \\ 7. 実プロセスにおける分散技術 \\ 8. トピックス
}

本書は(社)日本粉体工業技術協会・サブミクロン分科 会（コーティネータ・向阪保雄・阪府大教授）が中心亡 なり企画されたものである。

これまでにも「微粒子」を含む成書が幾つか刊行され ているが, 本書では微粒子と分散に焦点をあてている。 粉体を取り扱う際に単なる固体では済まなく，そのため に粉体工学が発展して来たように，微粒子になるとこれ までの粉体としての取扱いでは不十分となる例が現れ る。その一つに微粒子の分散・付着・凝集があり, 特に 材料製造プロセスでは原料の微細化に伴い緊急性が高い 課題である。

本書は, 微粒子の分散, これと表裏一体である付着・ 凝集が以下に紹介する各章で論じられている。

1. 微粒子の分散の難しさ

2. 微粒子間にどのような力が勳くのだろうか

3. 微粒子の分散をどのように考えるか
凝集の「原理と基礎」は？凝集の「評価」は？ 如 何なる「対策」があるのか？実プロセスでの「事例」 は? 「新しい応用」は？と言った具合に，基礎 $\rightarrow$ 応 用 $\rightarrow$ トピックスが明快に展開されている。また, 章題か らは, 新しくかつ困難な問題をできるだけ平易に解説す る意志が感じられる。実際, 固/固, 固/気及び固／液 系にわたる多様な分野からの一流の研究者・技術者によ る執筆内容はこの方針に応えたものである。微粒子に限 らず，粉体全般を見直すためにも有益である。粉体・微 粒子プロセスに携わる者に是非一読を薦めたい。

（名古屋工業大学・高橋

実) 